\title{
Combining Low Price, Low Climate Impact and High Nutritional Value in One Shopping Basket through Diet Optimization by Linear Programming
}

\author{
Corné van Dooren ${ }^{1,2, *}$, Marcelo Tyszler ${ }^{3}$, Gerard F. H. Kramer ${ }^{3}$ and Harry Aiking ${ }^{2}$ \\ 1 Netherlands Nutrition Centre (Voedingscentrum), Eisenhowerlaan 108, \\ 2508 CK The Hague, The Netherlands \\ 2 Institute for Environmental Studies, VU University, Boelelaan 1087, 1081 HV Amsterdam, \\ The Netherlands; E-Mail: harry.aiking@vu.nl \\ 3 Blonk Consultants, Gravin Beatrixstraat 34, 2805 PJ Gouda, The Netherlands; \\ E-Mails: marcelo@blonkconsultants.nl (M.T.); gerard@blonkconsultants.nl (G.F.H.K.) \\ * Author to whom correspondence should be addressed; E-Mail: dooren@voedingscentrum.nl; \\ Tel.: +31-70-306-88-56.
}

Academic Editor: Marc A. Rosen

Received: 5 June 2015 / Accepted: 14 September 2015 / Published: 18 September 2015

\begin{abstract}
Background: This study aims to find diets with low price and low climate impact, yet fulfilling all nutritional requirements. Methods: Optimization by linear programming. The program constrains 33 nutrients to fulfill Dutch dietary requirements. In a second cycle, the upper boundary for climate impact through greenhouse gas emissions (GHGE) is set to $1.6 \mathrm{~kg}$ carbon dioxide equivalents/day $\left(\mathrm{CO}_{2} \mathrm{eq}\right)$. In a third cycle, the costs are set on $€ 2.50$ as a constraint. The objective function of the optimization maximized the most consumed food products $(n=206)$ for male and female adults separately (age 31-50). Results: A diet of 63 popular and low priced basic products was found to deliver all required nutrients at an adequate level for both male and female adults. This plant-based, carbohydrate and fiber-rich diet consists mainly of wholegrain bread, potatoes, muesli, open-field vegetables and fruits. The climate impact of this diet is very low (1.59 $\mathrm{kg} \mathrm{CO} 2 \mathrm{eq} /$ day) compared to the average Dutch diet. By constraining costs, a low carbon diet of $€ 2.59 /$ day is possible. Conclusions: A two-person diet consisting of 63 products and costing $€ 37$ per week can simultaneously be healthy and yet have half the average climate impact. Linear programming is a promising tool to combine health and sustainability on both societal and individual levels.
\end{abstract}


Keywords: climate impact; greenhouse gas emissions; nutritional adequacy; affordable food; linear programming; sustainable diets

\section{Introduction}

Over 25 years ago, Brundtland [1] was among the first to call for sustainable development. However, the focus on sustainable diets is much more recent. Not until 2010 did the Food and Agriculture Organization of the United Nations (FAO) [2] publish a definition of sustainable diets: "Sustainable Diets are those diets with low environmental impacts which contribute to food and nutrition security and to healthy life for present and future generations". The scientific challenge is to explore and identify healthy and affordable diets with minimal environmental impact for every citizen.

Various European studies have indicated that existing dietary guidelines do not only improve health, but are also generally more eco-friendly [3-5]. In the UK, for instance, the Advice to Government on priority elements of sustainable diets [3] (a review of 44 scientific publications) identified three changes likely to have the most significant and immediate impact on making our diets more sustainable and in which health, environmental, economic and social impact are more likely to complement each other. These changes are: (1) reducing consumption of meat and dairy products; (2) reducing consumption of food and drink of low nutritional value (i.e., fatty and sugary foods); and (3) reducing food waste [3]. Two years later, the Health Council of the Netherlands [4] came to a similar conclusion: "In general terms, a shift from the usual diet towards that described in the Guidelines for a healthy diet is not only good for the health, but would also seem to be beneficial in terms of land use and greenhouse gas emissions." They came up with four recommendations, of which three were very similar to those of the British. The Health Council concluded that the fourth guideline - the recommendation to eat two portions of fish a week - may yield health benefits but may also be ecologically detrimental, particularly to marine biodiversity [4]. The Italian study resulting in the Double Pyramid [5] showed for the Mediterranean diet that the lower the ecological footprint of a food product, the more preferable the product is in terms of health benefit. Other countries such as Sweden [6], Germany [7], Finland [8] and Belgium [9] also issued clear dietary recommendations based on sustainability. Achieving food system sustainability is a global priority, but there are different views on how it might be achieved: efficiency orientation, demand restraint and food system transformation require simultaneous efforts by government, industry and consumer [10]. This paper focuses on demand restraint by changing towards sustainable diets, because efficiency-focused technological measures alone, while important, may not be sufficient in reducing greenhouse gas emissions (GHGE) to the level required [11]. Recently, the US Dietary Guidelines Advisory Committee concluded that access to sufficient, nutritious, and safe food is an essential element of food security for the population. A sustainable diet ensures this access for both the current population and future generations [12].

The underlying reason to focus on sustainable diets is that food is the largest contributor to global warming [13]: $20 \%$ to $35 \%$ of greenhouse gas emissions (GHGE) and one-third of the land use (LU) is related to the production of food $[11,14,15]$. The science behind calculating the environmental impacts 
of diets is still in its infancy. Nutrition is affected by numerous environmental and societal causes. Herforth et al. [16] suggested a simple framework based on three domains: nutritional quality, economic viability, and environmental sustainability. Our study is in line with their call for an integrated approach in research to simultaneously address all three domains. One of the conclusions of the Health Council of the Netherlands was that the 2011 state of knowledge permitted only qualitative, rather than quantitative guidelines [4]. Therefore, this paper aims to contribute to the development of models for quantification of sustainable and healthy menus and diets.

The present Dutch diet is not in line with the dietary guidelines [17,18]. The Dutch still eat too little fruit, vegetables, fish and fiber. Only $3 \%-14 \%$ of the adults comply with the recommendations for fruits and vegetables and $13 \%-33 \%$ with those for fish. The proportion of saturated fatty acids in the diet is still unfavorable and obesity is common [19]. Current trends in food production and consumption are considered unsustainable. The average Dutch diet is less sustainable, in terms of GHGE and LU, than eating according to the Dutch dietary guidelines by choosing healthier options. Further improvements are within reach, we concluded in a recent paper [20]. In an earlier scenario type study, we analyzed six diets with the aim to explore how health and nutrition can be improved, while simultaneously decreasing the environmental impacts [20]. To explore both health and sustainability scores of the current Dutch diet, we analyzed diets with a health focus (such as the Mediterranean diet), diets with an animal protein reduction focus (vegan and vegetarian), and combinations. We found that healthier and more sustainable diets go largely hand in hand. As anticipated, a shift from the current Dutch diet to a more health-focused diet according to the Dutch dietary guidelines will have a significant positive effect on GHGE and the area of land used for production. GHGE decreased by $11 \%$ and LU by $38 \%$ for a diet that satisfies the dietary guidelines. The lowest impact was found in the vegan diet (up to $35 \%$ reduction in GHGE and $59 \%$ in LU) [20].

Nevertheless, we do expect that linear programming will make it possible to find diets and product suggestions with even lower impacts than these scenario studies. Several studies in other countries-For instance the UK, France and New Zealand-Have successfully used linear programming for diet optimization [21-29]. Some of these studies demonstrated that cost constraints have a negative impact on nutritional values, and others showed that a healthy diet will not always have lower GHGE [30]. As far as we know, only two studies explored nutritional constrains as well as affordability and climate impact [29,30]. The first one resulted in a $25 \%$ reduction in climate impact, with costs comparable to the average UK diet ( €4.80/d) [30]. The second one resulted in a diet which was low in costs $(\sim € 1.92-2.44 / \mathrm{d})$, but did not meet the nutritional requirements on fruit and vegetable intake and did not include drinks [29]. We want to explore these effects for Dutch diets: adult male and female diets, combined in a two-person household shopping basket. The aim of this paper is to identify nutritionally adequate diets, by linear programming, which are both low in climate impact and affordable.

\section{Methods}

\subsection{Nutritional Data}

The nutritional data are taken from the Dutch Nutrient Database (Nederlands Voedingsstoffenbestand; NEVO) [31], which contains macro- and micronutrients of more than 2000 common food products, 
including the 206 products used in this study. Portions are supplied by the Nutrition Centre table "Weights and Measures" [32].

The diets investigated are based on the average Dutch consumption for males $(n=348)$ and females $(n=351)$, age 31-50, collected in the Dutch National Food Consumption Survey 2007-2010 [19]. Numerous quality checks were performed to exclude underreporting or overreporting. Nevertheless, underreporting on energy intake may occur: The proportion of low reporters was $17 \%$, based on energy intake, while the proportion of high energy reporters was $1.5 \%$, which is in line with the underreporting from other studies [19].

The actual selected consumption profiles of 83 food products for men and 73 food products for women used in the optimization cover, respectively, $74 \%$ and $73 \%$ of the total consumption in kcal. The product group "miscellaneous" is a correction based on energy intake for the remaining products ( $26 \%$ vs. 27\%) outside the 206 products in our database (see Table 1). The data of the miscellaneous group are based on national statistics of consumption (weight and energy) [19] and on earlier studies on GHGE emissions [33] and diet costs [34]. The proportions in the average diet of the known product groups are almost kept the same as the proportions of the total diet from the food consumption survey. If the non-alcoholic drinks for instance account for $7 \%$ of the kcal, then $7 \%$ of the known products and $7 \%$ of the unknown products (the miscellaneous group) are non-alcoholic drinks. This correction could result in a margin of error, which asks prudence by the interpretation of the results.

The recommendations used for 33 macro- and micronutrients are given by the Netherlands Nutrition Centre [32] and the Health Council of the Netherlands [17,35,36], including all official recommendations.

\subsection{Environmental Data}

We calculate four ecological indicators as a proxy for sustainability: GHGE, LU, fossil energy use and an approximation of ReCiPe (the ReCiPe abbreviation reflects the initials of the institutes RIVM, CML, PRé Consultants contributing to this method [37]). ReCiPe is a weighted combination of these three indicators. GHGE consider the global warming potential of $\mathrm{CO}_{2}$, methane and $\mathrm{NO}_{\mathrm{x}}$ according to the Intergovernmental Panel on Climate Change [38]. Our calculation of these ecological indicators is based on a Life Cycle Assessment (LCA) for the most consumed products in the diets [39]. LCA is a methodological framework for assessing the environmental impacts that are attributable to the life cycle of a product, such as climate change, toxicological impacts on human health and ecosystems, depletion of resources, water use and LU [40]. LCA standards and handbooks currently in use are the ISO 14040/44 series and the ILCD handbook (International Reference Life Cycle Data System) [41]. For further details on the LCA methodology we use, see "The Agri-footprint method; Methodological LCA framework, assumptions and applied data, Version 1.0" [40]. The life cycle boundary goes from raw materials acquisition and natural resources to final disposal, including food waste, and contains some estimate of energy use for cooking and preparation at home. The ReCiPe method aggregates several other LCA impact indicators, including water pollution and human toxicology, comprising harmonized category indicators at the midpoint and the endpoint levels [37]. Water use is not included in this study, because the needed data are not available in the LCAs we used. In LCAs of agricultural products, the main contributors to this end score are GHGE, LU, and fossil energy use [42]. In the 
scope of this study, it was not possible to carry out an extensive assessment to define standard deviations for the parameters. LCA experts assume a general uncertainty of $10 \%$ to $20 \%$ in our results [40].

\subsection{Economic Costs}

Nibud (Dutch National Institute for Family Finance Information) monitors and calculates the economic costs of households, including diets. The actual, average diet costs per day per person in a 2-person household are $€ 6.40$ for males and $€ 5.82$ for females [34]. Average prices of food products fluctuate day by day, and are not monitored in The Netherlands. Economic costs of food items in the model are based on prices prevailing at the moment of this study (April 2013) charged in the web shop of the largest Dutch supermarket chain, Albert Heijn (webwinkel.ah.nl). When different brands of the same product are available, the cheapest one is selected.

\subsection{Linear Programming}

Linear programming is a mathematical technique that allows the generation of optimal solutions [43]. Linear Programming Models for human diets were first applied and published in the 1950s [44]. The method for linear programming we use in this study is very similar to the one used by Macdiarmid for the World Wildlife Fund Livewell Plate [21] and which was scientifically described by Macdiarmid et al. in 2012 [45]. This mathematical method optimizes an outcome that is a linear function of several variables that can be controlled (e.g., the amount of food eaten), while subject to a number of constraints (e.g., dietary requirements) [21].

The programmed linear programming algorithm minimizes the absolute changes in terms of portions to the current diet [22], weighted by a proxy of popularity, while satisfying a number of constraints. Due to the weighting, it penalizes positive deviations from the current diet differently from negative deviations. For example, adding a popular product is penalized less than adding a non-popular product, while removing a popular product is penalized more than removing a non-popular product. Popularity is measured as the total quantity of a product consumed in the sample population during the Food Consumption Survey [19]. More specifically the optimization weights are constructed from the normalized value of the total food consumption based on weight ( $n=206$, [19]) for male and female adults (age 31-50). The proxy for popularity is first normalized, which creates a value between 0 and 1 . For positive deviations, the optimization weights are a number between 1 and 2, such that the most popular product has an optimization weight equal to 1 . For negative deviations, the optimization weights are a number between 1 and 2, such that the most popular product has an optimization weight equal to 2. Subsequently, the objective function is the summation of the weighted positive changes with the weighted negative changes. This aggregated total is minimized. The solutions are sets of alternative diets within the feasible region, with the algorithm favoring the solution closest to the initial situation, i.e., diet. 
Table 1. (a) male and (b) female adults: Composition of the average and optimized diet (after three cycles), and the differences between them by product groups in weight (g per day), energy supply (kcal), and impact in terms of greenhouse gas emissions (GHGE; kg COzeq) and costs (Euro).

\begin{tabular}{|c|c|c|c|c|c|c|c|c|c|c|c|c|}
\hline \multirow{2}{*}{$\begin{array}{l}\text { (a) Male (Age 31-50) } \\
\text { Product Group }\end{array}$} & \multicolumn{3}{|c|}{ Weight (g) } & \multicolumn{3}{|c|}{ Energy (kcal) } & \multicolumn{3}{|c|}{ GHGE $\left(\mathrm{kg} \mathrm{CO} \mathrm{CO}_{2} \mathrm{eq}\right)$} & \multicolumn{3}{|c|}{ Costs (Euros) } \\
\hline & $\begin{array}{c}\text { Average } \\
\text { Diet }\end{array}$ & $\begin{array}{c}\text { Optimized } \\
\text { Diet } \\
\end{array}$ & Difference & $\begin{array}{c}\text { Average } \\
\text { Diet }\end{array}$ & $\begin{array}{c}\text { Optimized } \\
\text { Diet } \\
\end{array}$ & Difference & $\begin{array}{c}\text { Average } \\
\text { Diet }\end{array}$ & $\begin{array}{c}\text { Optimized } \\
\text { Diet } \\
\end{array}$ & Difference & $\begin{array}{c}\text { Average } \\
\text { Diet }\end{array}$ & $\begin{array}{c}\text { Optimized } \\
\text { Diet } \\
\end{array}$ & Difference \\
\hline Potatoes & 99 & 111 & 12 & 135 & 172 & 38 & 0.15 & 0.21 & 0.05 & $€ 0.06$ & $€ 0.07$ & $€ 0.01$ \\
\hline Alcoholic drinks & 206 & 0 & -206 & 102 & & -102 & 0.13 & & -0.13 & $€ 0.25$ & & $-€ 0.25$ \\
\hline Non-alcoholic drinks & 1252 & 1443 & 191 & 135 & 15 & -120 & 0.32 & 0.13 & -0.19 & $€ 0.41$ & $€ 0.05$ & $-€ 0.35$ \\
\hline Bread & 144 & 225 & 81 & 346 & 536 & 190 & 0.13 & 0.20 & 0.07 & $€ 0.27$ & $€ 0.39$ & $€ 0.12$ \\
\hline Eggs & 11 & 0 & -11 & 16 & & -16 & 0.03 & & -0.03 & $€ 0.03$ & & $-€ 0.03$ \\
\hline Fruits & 83 & 200 & 117 & 58 & 141 & 84 & 0.06 & 0.12 & 0.06 & $€ 0.15$ & $€ 0.34$ & $€ 0.19$ \\
\hline Cakes & 42 & 42 & 0 & 150 & 150 & 0 & 0.06 & 0.06 & 0.00 & $€ 0.14$ & $€ 0.14$ & $€-$ \\
\hline Cereals & 49 & 49 & 0 & 81 & 81 & 0 & 0.06 & 0.06 & 0.00 & $€ 0.05$ & $€ 0.05$ & $€-$ \\
\hline Vegetables & 74 & 200 & 126 & 21 & 64 & 43 & 0.12 & 0.17 & 0.05 & $€ 0.12$ & $€ 0.25$ & $€ 0.13$ \\
\hline $\begin{array}{l}\text { Spreads (peanut butter, } \\
\text { humus, hazelnut paste) }\end{array}$ & 9 & 30 & 20 & 63 & 196 & 133 & 0.02 & 0.05 & 0.04 & $€ 0.03$ & $€ 0.09$ & $€ 0.06$ \\
\hline Cheese & 32 & 0 & -32 & 114 & & -114 & 0.38 & & -0.38 & $€ 0.35$ & & $-€ 0.35$ \\
\hline Milk and milk products & 317 & 32 & -284 & 183 & 15 & -168 & 0.42 & 0.05 & -0.38 & $€ 0.27$ & $€ 0.02$ & $-€ 0.24$ \\
\hline Nuts, seeds and snacks & 14 & 54 & 40 & 74 & 326 & 252 & 0.03 & 0.08 & 0.05 & $€ 0.06$ & $€ 0.23$ & $€ 0.17$ \\
\hline Legumes & 0 & 125 & 125 & & 148 & 148 & & 0.16 & 0.16 & & $€ 0.16$ & $€ 0.16$ \\
\hline Soy products (soy drink) & 0 & 412 & 412 & & 156 & 156 & & 0.16 & 0.16 & & $€ 0.41$ & $€ 0.41$ \\
\hline Sugar and confectionary & 27 & 27 & 0 & 116 & 116 & 0 & 0.05 & 0.05 & 0.00 & $€ 0.09$ & $€ 0.09$ & $€-$ \\
\hline Fats, oils and sauces & 49 & 47 & -2 & 193 & 178 & -15 & 0.11 & 0.08 & -0.03 & $€ 0.14$ & $€ 0.13$ & $-€ 0.01$ \\
\hline Fish & 9 & 10 & 2 & 16 & 31 & 14 & 0.07 & 0.01 & -0.06 & $€ 0.12$ & $€ 0.12$ & $€ 0.00$ \\
\hline Meat and meat products & 66 & 7 & -59 & 154 & 23 & -132 & 0.43 & 0.03 & -0.40 & $€ 0.65$ & $€ 0.06$ & $-€ 0.59$ \\
\hline Miscellaneous ${ }^{1}$ & 552 & 0 & & 691 & 0 & & 0.90 & 0.00 & & $€ 1.11$ & $€-$ & \\
\hline Total & 3033 & 3013 & $-1 \%$ & 2647 & 2348 & $-11 \%$ & 3.46 & 1.60 & $-54 \%$ & $€ 4.28$ & $€ 2.59$ & $-40 \%$ \\
\hline
\end{tabular}


Table 1. Cont.

\begin{tabular}{|c|c|c|c|c|c|c|c|c|c|c|c|c|}
\hline \multirow{2}{*}{$\begin{array}{c}\text { (b) Female (Age 31-50) } \\
\text { Food Groups }\end{array}$} & \multicolumn{3}{|c|}{ Weight (g) } & \multicolumn{3}{|c|}{ Energy (kcal) } & \multicolumn{3}{|c|}{ GHGE (kg CO를 } & \multicolumn{3}{|c|}{ Costs (Euros) } \\
\hline & $\begin{array}{c}\text { Average } \\
\text { Diet }\end{array}$ & $\begin{array}{c}\text { Optimized } \\
\text { Diet }\end{array}$ & Difference & $\begin{array}{c}\text { Average } \\
\text { Diet }\end{array}$ & $\begin{array}{c}\text { Optimized } \\
\text { Diet }\end{array}$ & Difference & $\begin{array}{c}\text { Average } \\
\text { Diet }\end{array}$ & $\begin{array}{c}\text { Optimized } \\
\text { Diet }\end{array}$ & Difference & $\begin{array}{c}\text { Average } \\
\text { Diet }\end{array}$ & $\begin{array}{c}\text { Optimized } \\
\text { Diet }\end{array}$ & Difference \\
\hline Potatoes & 74 & 74 & 0 & 95 & 95 & 0 & 0.11 & 0.11 & 0.00 & $€ 0.05$ & $€ 0.05$ & $€-$ \\
\hline Alcoholic drinks & 30 & 0 & -30 & 25 & & -25 & 0.04 & & -0.04 & $€ 0.09$ & & $-€ 0.09$ \\
\hline Non-alcoholic drinks & 1345 & 1266 & -79 & 95 & 62 & -34 & 0.25 & 0.18 & -0.07 & $€ 0.35$ & $€ 0.18$ & $-€ 0.17$ \\
\hline Bread & 113 & 113 & 0 & 275 & 275 & 0 & 0.10 & 0.10 & 0.00 & $€ 0.21$ & $€ 0.21$ & $€-$ \\
\hline Eggs & 10 & 10 & 0 & 14 & 14 & 0 & 0.03 & 0.03 & 0.00 & $€ 0.03$ & $€ 0.03$ & $€-$ \\
\hline Fruits & 102 & 200 & 98 & 71 & 164 & 92 & 0.07 & 0.17 & 0.10 & $€ 0.19$ & $€ 0.41$ & $€ 0.22$ \\
\hline Cakes & 40 & 40 & 0 & 144 & 144 & 0 & 0.06 & 0.06 & 0.00 & $€ 0.14$ & $€ 0.14$ & $€-$ \\
\hline Cereals & 39 & 39 & 0 & 66 & 66 & 0 & 0.04 & 0.04 & 0.00 & $€ 0.04$ & $€ 0.04$ & $€-$ \\
\hline Vegetables & 70 & 200 & 130 & 19 & 58 & 39 & 0.10 & 0.21 & 0.11 & $€ 0.11$ & $€ 0.30$ & $€ 0.18$ \\
\hline $\begin{array}{l}\text { Spreads (peanut butter, } \\
\text { humus, hazelnut paste) }\end{array}$ & 6 & 6 & 0 & 37 & 37 & 0 & 0.01 & 0.01 & 0.00 & $€ 0.02$ & $€ 0.02$ & $€-$ \\
\hline Cheese & 27 & 0 & -27 & 98 & & -98 & 0.32 & & -0.32 & $€ 0.30$ & & $-€ 0.30$ \\
\hline Milk and milk products & 232 & 50 & -183 & 112 & 22 & -90 & 0.34 & 0.07 & -0.27 & $€ 0.19$ & $€ 0.04$ & $-€ 0.15$ \\
\hline Nuts, seeds and snacks & 11 & 49 & 38 & 60 & 299 & 240 & 0.02 & 0.07 & 0.04 & $€ 0.05$ & $€ 0.21$ & $€ 0.16$ \\
\hline Legumes & 0 & 194 & 194 & & 219 & 219 & & 0.25 & 0.25 & & $€ 0.24$ & $€ 0.24$ \\
\hline Soy products (soy drink) & 0 & 417 & 417 & & 159 & 159 & & 0.16 & 0.16 & & $€ 0.41$ & $€ 0.41$ \\
\hline Sugar and confectionary & 25 & 30 & 5 & 104 & 115 & 11 & 0.04 & 0.05 & 0.01 & $€ 0.10$ & $€ 0.11$ & $€ 0.01$ \\
\hline Fats, oils and sauces & 25 & 25 & 0 & 119 & 119 & 0 & 0.07 & 0.07 & 0.00 & $€ 0.08$ & $€ 0.08$ & $€-$ \\
\hline Fish & 1 & 10 & 9 & 1 & 31 & 30 & 0.01 & 0.01 & 0.00 & $€ 0.06$ & $€ 0.12$ & $€ 0.07$ \\
\hline Meat and meat products & 44 & 3 & -41 & 94 & 10 & -83 & 0.24 & 0.01 & -0.22 & $€ 0.49$ & $€ 0.03$ & $-€ 0.46$ \\
\hline Miscellaneous ${ }^{1}$ & 632 & 0 & & 528 & 0 & & 0.94 & 0.00 & & $€ 0.92$ & $€-$ & \\
\hline Total & 2827 & 2725 & $-4 \%$ & 1956 & 1888 & $-3 \%$ & 2.80 & 1.60 & $-43 \%$ & $€ 3.41$ & $€ 2.61$ & $-23 \%$ \\
\hline
\end{tabular}

${ }^{1}$ Note: The product group "miscellaneous" is a correction based on an energy intake for the remaining of products outside the 206 products in this study (see Methods). 
The total GHGE of a diet consisting of amounts of $\mathrm{n}$ food products $\left(x_{1}, x_{2}, \ldots, x_{n}\right)$ and the associated GHGE of each food product per unit weight (GHGEi) is as in Formula (1).

$$
G H G E_{\text {diet }}=\sum_{i=1}^{n} x_{i} G H G E_{i}
$$

In addition, the diet has to satisfy the energy and nutrient requirements (constraints) listed in Table 2 and, when applicable, an upper limit for total diet cost or GHGE. Each constraint can be denoted as $b_{1}, b_{2}, \ldots, b_{m}$, and with each food product $i$ contributing $a_{i j}$ per unit weight to requirement $j$, a set of $j$ dietary constraints was established as in Formula (2).

$$
b_{j} \geq \sum_{i=1}^{m} a_{i j} x_{i}
$$

Table 2. Nutritional constraints (33) and results after 3 cycles (nutrients, greenhouse gas emissions, and costs as constraints): nutritional value for male $v s$. female consumers.

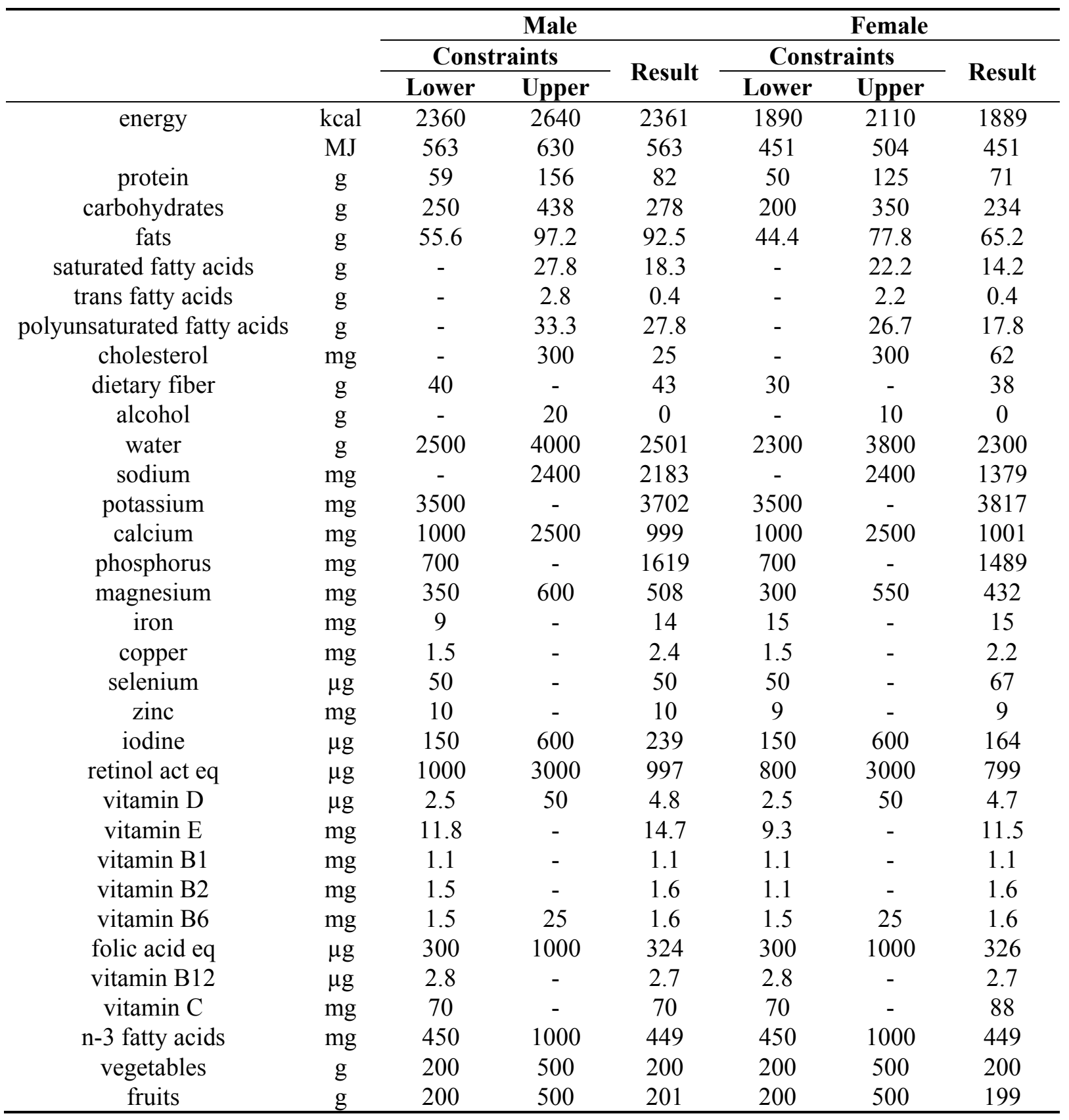


Optimization is done by linear programming using the newly developed Optimeal ${ }^{\circledR}$ software of Blonk Consultants and the Netherlands Nutrition Centre (Gouda, The Netherlands), which runs with MATLAB Compiler 7.16 and Microsoft Access Runtime.

\subsection{Constraints}

The initial starting point of this study is the average consumption of food by the Dutch population, as measured by the food consumption survey of 2007-2010 [19]. From this survey, we selected the largest population groups, i.e., male and female adults (age 31-50). This selection is done because every group has its own specific dietary recommendations. We determined the 206 most consumed products and added the data to our software tool, together with the average consumed quantities in portions per day (Figure 1; no constraints). The nutritional value of these products is derived from the Dutch Nutrient Database NEVO [31]. Blonk Consultants calculated the environmental impacts from these average consumption levels in an earlier study, as described in the environmental data section [33].

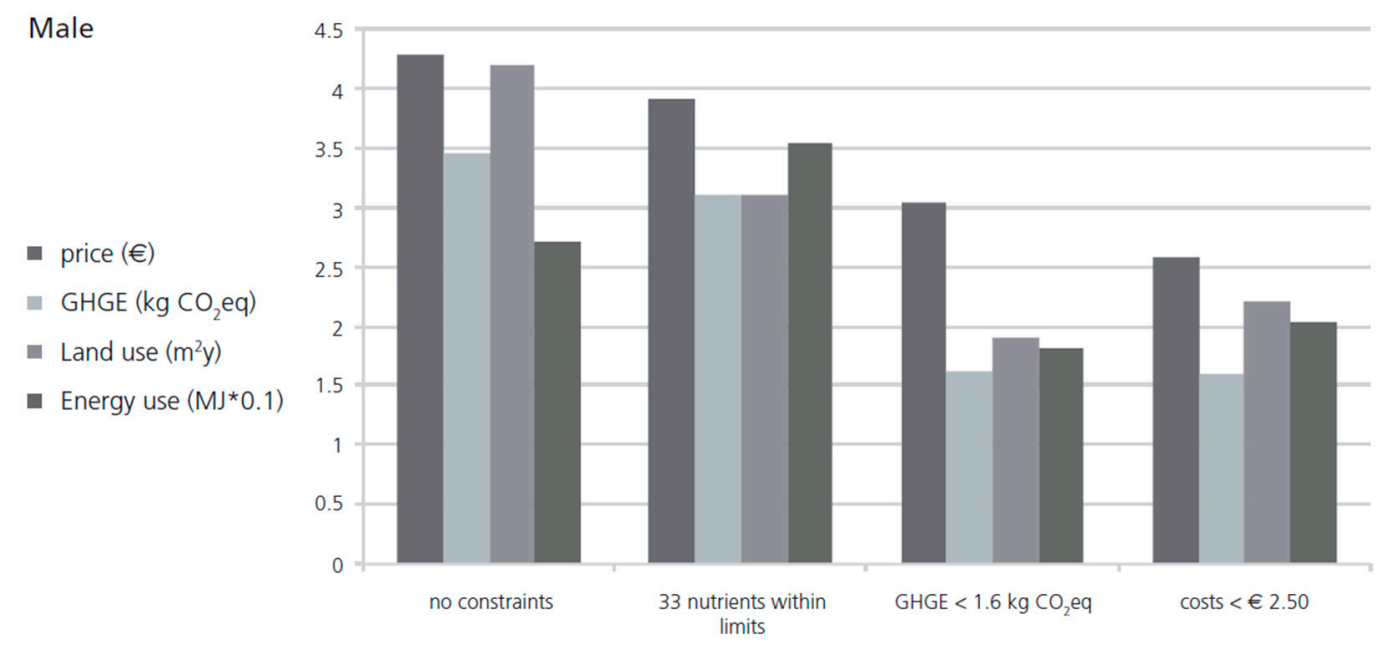

(a)

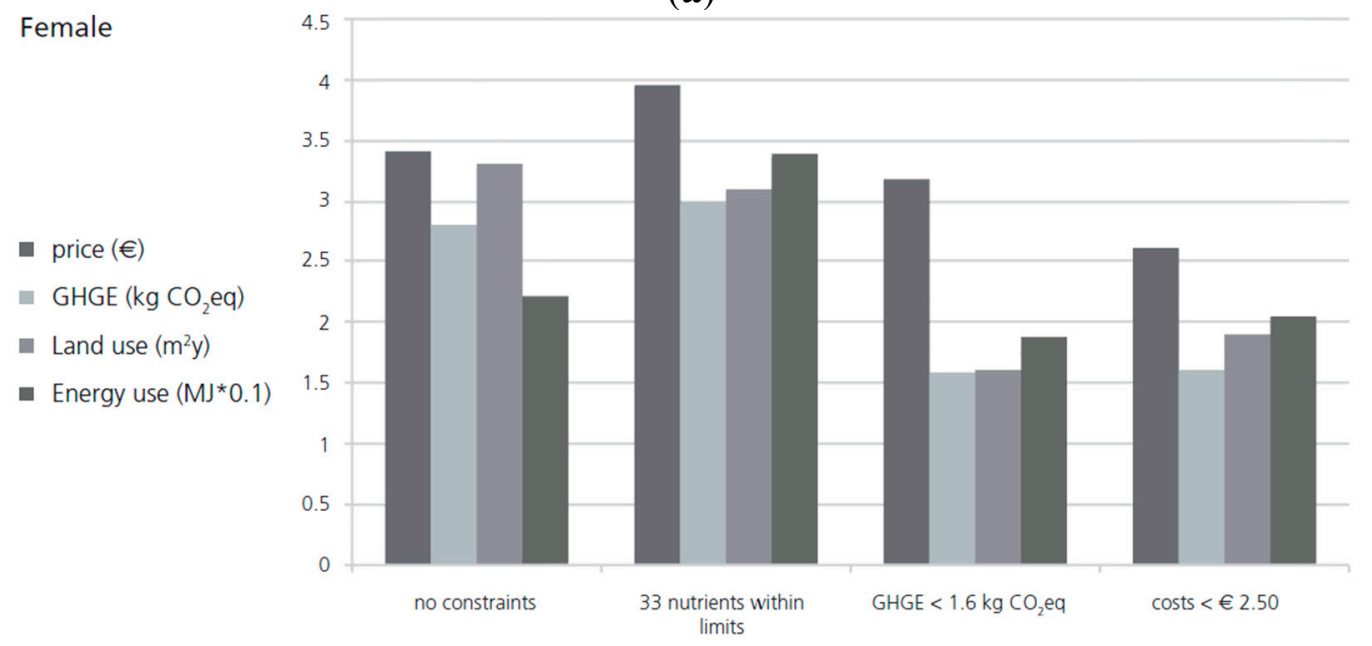

(b)

Figure 1. (a) Changes in greenhouse gas emissions (GHGE), land use (LU), energy use and price after three subsequent cycles with: (1) 33 nutrients, (2) GHGE, and (3) costs as constraints in linear programming compared to average consumption by male adults in 2007-2010; (b) Changes in constraints for female adults. 
Optimization is done in three separate, successive cycles with: (1) nutrients, (2) GHGE, and (3) costs as constraints, respectively. We made this separation to see the results of adding new constraints, but it does not influence the final results, when the constraints are set at the same time in one run. Cycle 1: Adequate intake levels and dietary guidelines of 33 nutrients are given by the Netherlands Nutrition Centre [32] and the Health Council of the Netherlands [17,35,36] as the first constraint (see Figure 1). The 33 nutrients and nutritional indicators are: energy, protein, carbohydrates, total fat, saturated fatty acids, trans fatty acids, polyunsaturated fatty acids, cholesterol, dietary fiber, alcohol, water, sodium, calcium, phosphorus, magnesium, iron, copper, selenium, zinc, iodine, retinol, vitamin D, vitamins B1, B2, B6, B12, folic acid, vitamin C, n-3 fatty acids (eicosapentaenoic acid and docosahexaenoic acid), fruit consumption and vegetable consumption. The model corrects for possible energy, fat, salt and carbohydrate overconsumption by constraints for energy, protein, carbohydrates, fats and sodium. Cycle 2: Secondly, the upper boundary for climate impact (GHGE) is set to $1.6 \mathrm{~kg}$ $\mathrm{CO}_{2} \mathrm{eq} /$ day. The $1.6 \mathrm{~kg}$ threshold is chosen as 50 percent reduction of the actual GHGE of the Dutch diet (3.2 kg CO $2 \mathrm{eq} /$ day; average of $3.5 \mathrm{~kg}$ for males and $2.8 \mathrm{~kg}$ for females [33]). A 50 percent reduction is chosen, because the European goal of keeping global warming below $2{ }^{\circ} \mathrm{C}$, requires worldwide emissions to be at least halved from 1990 levels by 2050 [46]. This constraint is also comparable to the $1.74 \mathrm{~kg} \mathrm{CO}$ eq calculated by Macdiarmid [21] as the biggest possible reduction (70\% for UK). LU, fossil energy use and ReCiPe score were not used as constraints but just as indicators of the sustainability of the diets. Cycle 3: In a third run, the costs of the diet per day are set at maximum $€ 2.50$ as a constraint. The $€ 2.50$ threshold is chosen as more than 50 percent reduction of the reference costs. Furthermore, $€ 2.50$ is relatively close to the 2 dollar per day poverty line of the World Bank. A 50 percent cost reduction is chosen as measurement for a significant reduction, and to have higher savings than in other studies $[29,30]$.

\section{Results}

Optimization on 33 nutrients as constraint results first in a nutritionally adequate diet (Cycle 1). As a result of Cycle 2 the software tool composes a diet with low GHGE, and in Cycle 3 a diet low in price and low in GHGE. This diet consists of 63 popular and low-priced basic products and delivers all required nutrients at an adequate level for both male and female adults. To give an overview, the results are summarized as weight (g), energy supply (kcal), GHGE (kg $\mathrm{CO}_{2} \mathrm{eq}$ ) and costs (Euro) per product group in Table 1. The table shows the results of the optimized diet after the three cycles of optimization or after one combined run.

The optimized diet is primarily plant-based (Table 1, optimized diet). It is rich in carbohydrates and fiber, and consists of wholegrain bread, potatoes, pasta, rice, open-field-As opposed to greenhouse-Vegetables, fruits, legumes, nuts, soy drink and some dairy. The diet is complemented with fish, eggs, spreads, low-fat margarine, coffee and tea to deliver other essential nutrients. Men and women have comparable patterns in the choice of food products and in the quantities consumed. The product groups potatoes; cereals; bread (for women only); cakes; sugar and confectionary; and fats, oils and sauces stay unchanged after optimization of the diets. Alcoholic drinks, soft drinks and juices were replaced by water, but coffee and tea volumes stay the same. Cheese, eggs (for men only), and meat are replaced by vegetal sources of protein, such as nuts and legumes, and some fish and liver 
spread (a popular spread for sandwiches). Dairy is partly replaced by soy drink. The quantities of vegetables and fruits are increased, with some changes to regional and open field varieties, such as pears and cabbages. The total volume and total caloric intake is decreased somewhat by 3 to 11 percent (Table 1). All products fit into the P95 consumption level (95th percentile of consumption among the population) of the current diet [19], except for legumes and soy drink. Nevertheless, the proposed volumes of these foods are normal for the groups of users in the Dutch population. The level of consumption of meat drops beneath the P05 level (95\% of the consumers eat $30 \mathrm{~g}$ of meat per day or more). If we set a minimum of, for instance, $50 \mathrm{~g}$ of meat (i.e., the actual Median consumption of fresh meat plus processed meat by women [19]) as an extra constraint, this has almost no effect of the outcome of the optimization (only LU and fossil energy use increase by 5\% for males and 8 and $4 \%$ for females, respectively), and some effect on the product choice.

Table 2 gives an overview of the nutritional values after Cycle 3 for male and female consumers, compared to the 33 constraints for the most important macro- and micronutrients. The resulting columns (after Cycle 3) show that almost all nutrient levels are between the required upper and lower limits. The fact that they are not exactly within the limits is a result of rounding of numbers of the nutrients per portion.

At $1.59 \mathrm{~kg} \mathrm{CO} 2 \mathrm{eq} /$ day (male and female) the climate impact of these diets after Cycle 3 is very low, compared to the average Dutch diet (males $3.5 \mathrm{~kg} \mathrm{CO}$ eq/day and females $2.8 \mathrm{~kg} \mathrm{CO} 2 \mathrm{eq} /$ day [33]). This means a $55 \%$ and $43 \%$ reduction of emissions for men and women, respectively. Other impacts such as fossil energy use and LU are also lower than average: Fossil energy use is 17.5 and 18.9 MJ/day, respectively (average of the actual diet 27.2 and 22.1 MJ/day); LU (average of the actual diet 4.2 and $3.3 \mathrm{~m}^{2} \times \mathrm{y} /$ day [33]), is more than halved to 2.0 and $1.6 \mathrm{~m}^{2} \times \mathrm{y} /$ day, respectively. The decrease in GHGE is caused mainly by a reduction of meat, dairy and drinks. Additionally, we tested GHGE as an objective function (instead of popularity), but this did not influence the final results.

The diet after Cycle 2 costs about $€ 3.20$ per person per day, which is affordable for the lowest income groups in the Netherlands. The costs for men (€3.23) and women (€3.18) are quite similar, and already almost half of the reference costs for an affordable diet according to Nibud. The weekly costs of this diet for a two-person household, which is the most common household size, amount to around $€ 45$ for this weekly shopping basket. By constraining costs in Cycle 3, lower prices are possible (€2.59), still combined with a low climate impact (1.58 $\mathrm{kg} \mathrm{CO} 2 \mathrm{eq} /$ day), but this results in a smaller variety in the diet (from 83 to 59 products for males and from 73 to 63 products for females). It appears impossible to reach the $€ 2.50$ goal value; $€ 2.59$ per day-Or about $€ 37$ per week for a two persons shopping basket-Appears to be the lowest possible cost at the price level of 2013.

Summarizing the results visually (Figure $1 \mathrm{a}$ for men and Figure $1 \mathrm{~b}$ for women) illustrates the differences in costs, GHGE, LU and energy use compared to the 2007-2010 average consumption. The constraints were run successively to show the effects of the individual constraints. Consequently, the first cycle reveals a rise in costs and fossil energy use and a decrease in LU for both sexes. Then, the second cycle results in a reduction of all three environmental parameters and also in costs. The final cycle yields lower costs without changes in environmental impact. Although the diets of men and women differ slightly, the trend within both sexes is almost the same, except the increase in GHGE in the first cycle for women. 


\section{Discussion}

Linear programming is a powerful tool, but this tool can lead to meaningless, unrealistic or infeasible results when models are crude and based on arbitrary decisions. In this section, we discuss the power of our model and compare the results with other studies. The novelty of this study lies in the inclusion of the use of (1) Dutch data on GHGE and LU data (which is unique in this type of studies); (2) an extensive list of nutrient constraints $(n=33)$; (3) a relatively large number of food products compared to similar studies (at $n=206$ ); (4) differentiated female and male diets; and (5) a proxy for popularity.

The latest step in the development and application of linear programming is the introduction of GHGE as a constraint. Before, Macdiarmid et al. found a realistic diet with a $25 \%$ to $36 \%$ reduction in GHGE $[21,45]$. Their study suggested that future work would need to integrate wider issues of sustainability into the modeling process and develop broader dietary advice [21]. Also Vieux et al. [25] published a scenario-based study (not linear programming) resulting in a maximum reduction of $12 \%$ in GHGE (3.60 kg CO2eq/day). The studies done by Macdiarmid et al. [21,45] and Vieux et al. [28] have limitations as they cover only a small range of food products ( 82 and 73 , respectively). Our study is more realistic and results in more options, by including the 206 most consumed food products in the Netherlands. Recently, Vieux et al. [47] expanded the French dataset (391 products) to look for associations between GHGE and nutritional quality, but without using linear programming. A recent New Zealand study resulted in a diet with only 10 to 19 food items (out of a database of 76), and was the first of its kind in combining nutrition, price and GHGE as constraints [29].

An asset of our study is that we use 33 nutrients and indicators, rather than 16 [45] or 18 [29] in other studies. It is clear from Table 2 that the optimized diet in its final form is not meeting constraints for some nutrients precisely, such as for calcium and retinol. This is the result of calculating in portions and rounding the results. The discrepancy is on the order of milligrams, which do not result in negative consequences for the health of the population.

Our study differs from the papers cited above [21,28] by finding much lower emission levels - In absolute terms-Although they observed substantial reductions in GHGE, as well. The resulting reduction to $1.56 \mathrm{~kg} \mathrm{CO}_{2}$ eq per day for the Netherlands is much lower than the 3.77-5.02 $\mathrm{kg}$ found for the UK and 3.6-4.2 kg for France. On the other hand, the result of a recent study in New Zealand is in the same order of magnitude: $1.62 \mathrm{~kg} \mathrm{CO}$ eq [29]. This may be explained by differences in the calculation methodology of GHGE per product. An important explanation is that in absolute terms the Dutch impact is lower than in other countries because of the higher efficiency in the agricultural sector or the shorter transport distances $[48,49]$. The GHGE of products, such as vegetables, is based on the current mix of import $v s$. export and open field $v s$. heated greenhouse production. An edited choice in consumer preferences could result in even lower emissions. Another possible explanation may be differences in eating habits and dietary patterns [50,51]. This confirms the importance of a country-by-country approach, without extrapolating results from one country to another, because of the differences in food patterns and climate impact of national products.

One of the most important results is that halving GHGE is possible within the existing dietary guidelines. So far such a result is achievable through linear programming exclusively, because manually searching for these solutions is too time consuming and complex [52]. Using scenario 
studies, the maximum calculated reduction in GHGE was 11\%-35\% [20], 19\% [53], or 12\% [28]. However, a scenario analysis, e.g., vegetarian diet, vegan diet, and Mediterranean style diet was beyond the scope of this study, but we explored them for the Dutch situation in an earlier study, which resulted in a lower reduction in GHGE [20]. In sum, linear programming was found to make it possible to find adequate dietary solutions with much lower impacts than scenario studies thus far. Scenario studies are based on assumptions, while Optimeal ${ }^{\circledR}$ linear programming software is calculating all possible options, purposely iterating towards a minimum to come up with the lowest values. Statistically the chance is very small to find the lowest value through a conceived scenario.

In our third cycle we introduce costs as a constraint. In contrast, most other studies using linear programming on diets focus on nutritional constraints exclusively [23,24,26,27,54], though some included cost successfully. The studies of Ferguson et al. [23,54] for instance, were carried out to improve Food-Based Dietary Guidelines and Food Aid. Two studies, performed in France [55] and the USA [56], also looked at the costs and, for the nutritionally optimal diet, found both an increase in costs. Our results as shown in Figure $1 \mathrm{a}$ and $1 \mathrm{~b}$ confirm the increase in costs compared to the initial diet for females (not for males), when using nutritional constraints exclusively. In contrast, adding environmental constraints results in a decrease in costs.

A recent review and meta-analysis including 27 studies in 10 countries by Rao et al. [57] provides evidence on the price differences between healthy and less healthy food patterns. Comparing nutrient-based patterns, healthier diets were $\$ 1.56$ more expensive per $2000 \mathrm{kcal}(\sim € 1.15)$. This highlights the challenges to reduce the financial barriers for healthy eating. Therefore, it is important that our approach led to a diet which costs as little as $€ 2.59$ per person per day. For comparison, the cost of food for the Livewell diet [21] was estimated to be around $€ 4.80$ a day. Though €3.20 the price level of a French study [55] was lower than the British study, the latter was without drinks and without GHGE as a constraint. The French diets provided little variety and deviated substantially from social norms. Finally, a New Zealand study results in a lower cost level of approximately $€ 1.92$ to 2.44 [29]. However, these low cost diets are very low in fruits and vegetables, in quantity and variety. Our result is substantially lower than the British and French price levels. The difference may be due to differences in price levels, but also to differences in dietary patterns between countries. The price levels in Dutch supermarkets are among the lowest in Europe. According to consumer research in the Netherlands, the actual cost of weekly groceries is about €82 [58]. In 2013, the Nibud [34] did a scenario study to calculate the minimum costs of a healthy weekly menu. The conclusion was that $€ 5$ per day for a healthy menu is feasible (range $€ 3.53-€ 5.10 /$ day), with a minimum of $€ 30$ per week per person. This paper demonstrates that by using linear programming with costs as a constraint (Cycle 3 ), a much lower price is achievable.

The most important challenge to improve the Optimeal ${ }^{\circledR}$ software in the future is to add even more food products with their environmental data. The 206 products in the model cover as much as $80 \%$ of the initial nationally consumed diet on a weight basis. Due to the fact that the not included products are generally more energy dense, no more than three quarters of the energy consumption is covered (see Table 1). This is a limitation to this study, because some of the energy dense products may have a high climate impact or price. The most popular alcoholic drinks are included (men $180 \mathrm{~mL}$ beer and $25 \mathrm{~mL}$ wine, women $30 \mathrm{~mL}$ wine). After optimization, alcoholic drinks are excluded, even though the upper limit allows one or two consumptions per day, respectively (see Table 1). As anticipated, a shift 
in alcohol consumption and sugared drinks towards tap water simultaneously reduces energy consumption, climate impact and costs. In fact, male alcohol consumption is partly responsible for the differences between male and female results, but its impact is small in our example. Excluding alcohol accounts for four percent of the GHGE and calories, and for six percent of the costs. Furthermore, replacing sugared drinks with tap water also accounts for 2.5 to 5 percent of the GHGE.

The OptimealC tool calculates optimal solutions, during which the algorithm favors through the proxy the solution that lies closest to the initial situation, i.e., diet. This means that other solutions are possible as a set of alternatives within the feasible range. Higher nutritional or lower climate impact solutions are available, but these are penalized as too far away from the initial diet or requiring extensive adjustments from consumers. Improvements in methodology have been made by using more nutrients (33) and most frequently consumed foods, resulting in more realistic diets than other studies [22,25]. Maillot et al. improved linear programming of diets in another way by using a goal function to maximize the most frequently consumed foods, without replacing more than five products from the original diet [22]. We implemented this improvement by using a unique objective function maximizing the most consumed food products based on weight and minimizing absolute change in portions as calculated (see the Methods section). For example, in the diet of men, 50 of the 83 products were kept unchanged in number of portions, and 55 of the 73 products in the diet of women. The tool calculated a change in number of portions for four foods for men and seven for women. Finally, for men, 10 new food items were added to the diet and for women eight (i.e., unsalted peanuts, pear, kale, sauerkraut, lentils, marrowfats, humus, soy drink, mackerel and mussels). However, the character of the diet was substantially changed from normal portions of meat and dairy to an almost vegetarian pattern. For a part of the population, it is common to leave out regularly animal products from their diet. According to the food consumption survey [19] half of the population did not consume milk on the recorded days, three quarters did not consume eggs, a third did not consume cheese and 10 to 14 percent did not consume meat, poultry and meat products at all. Likewise, new protein-rich products such as soy drink, marrowfats and lentils were introduced in reasonable quantities, because they are only consumed by a small part of the population nowadays (one to four percent) [19]. One limitation of the methodology is the lack of scope for optimization using less popular foods, which is a methodological choice, not a technical limitation. Less common foods and new protein alternatives, such as algae, seaweed and meat substitutes, could be interesting for policy makers to include. It is possible to force the linear programming software to include a maximum of $25 \%$ reduction in consumption per product group, for example, down to $238 \mathrm{~mL}$ milk and $50 \mathrm{~g}$ of meat in the male diet. Even then the constraints of GHGE and costs can be met. Nevertheless this results in bigger changes in other product groups (bread, potatoes, snacks, and cakes) and in more product changes in total.

Variation of the optimized diet is enhanced by setting a maximum number of portions per week for each vegetable, fruit and spread (such as peanut butter) in the software. The vegetable group consists of more than seven common vegetables per week. The carbohydrates group, for instance, includes potatoes (twice a week), pasta, rice, French fries and legumes (twice). In Table 1 we see a shift from sandwich spreads such as cheese and cold cuts towards different spreads: peanut butter, humus, hazelnut and liver spread. A final remark concerns the choice of fish in the diet. The tool selected mackerel as the best nutritional solution, but this is not the most sustainable fish in the North Sea, even 
though it is not overfished at the moment. We have addressed the feasibility issue by showing that a lot of products and product groups remain unchanged (60 to 75 percent), however, some changes in the other products may not be accepted by the majority of the consumers in the short term, especially the strong reductions in dairy and meat. Although the study was designed to have the lowest number of possible changes, it resulted in the quasi elimination of two food categories (meat and cheese) and the introduction of a new one (soy products). Nevertheless, the solutions given are more varied than those of most other studies. In our opinion, the optimization offers a reasonable diet with realistic and feasible combinations of foods, such as potatoes, vegetables and fish or meat substitute; bread, margarine and spreads; and coffee and tea with cakes or sweets. Substantial variability across subgroups based on socio economic status, age, and values, may mean that the average diet does not actually represent anybody's dietary practices. This implicates the need for future research across subgroups. We recommend future research to include higher numbers of products including more environmental data and research focusing on a larger geographical area, comparing different countries. Such studies could support food policies that enable large sections of the population to eat healthy, affordable and sustainable diets, and food companies and retailers to enlarge their portfolio of products that fits into these diets. This field of research can be improved by: (a) making the model suitable to include subgroup and other age groups analysis with different dietary practices; (b) adding more variables to the environmental impact, for instance water use; (c) developing further an integrated approach for the concept of nutritional quality; and (d) developing further the notion of minimizing changes to the existing diet, so that it is more easily accepted by the population.

\section{Conclusions}

Linear programming models could be too crude and infeasible, but our model addresses this issue through considerable constraints and a popularity proxy. In contrast to most other studies focusing on nutritional constraints exclusively, we managed to integrate wider issues of sustainability (GHGE, land use and energy use) into the modeling process and to develop broader dietary advice. In parallel with Wilson et al. [29] our study is unique in combining three dimensions: nutrients, GHGE, and costs. We showed that a reasonable two-person diet (male and female) in one shopping basket, consisting 63 products - Consumed by the majority of Dutch consumers - And costing €37 per week can supply adequate nutrients at half the climate impact of the current average diet. So far, such a result was demonstrated to be achievable through linear programming exclusively. It is inevitable that a lower environmental impact and lower costs are found than in scenario studies and comparable studies in other countries. Evaluating the limited number of studies done in the field of linear programming of diets, we conclude that linear programming is a promising tool, making it possible to identify healthy and affordable diets with minimal environmental impacts on both societal and individual levels. Improvement of the tool is possible by adding more food items, together with their environmental parameters, with a maximum number of portions per week, to guarantee a varied diet. This study demonstrates that by means of linear programming a healthy and sustainable diet can be found which is affordable for the lowest income groups in the Netherlands. 


\section{Acknowledgments}

We thank professor Pier Vellinga for his constructive feedback and useful suggestions. We thank the British, Belgian and French Nutrition Societies for having the opportunity to give an oral presentation of the first results from this study at the Sustainable Diet and Food Security conference 2013 in Lille, France. This work was supported by a grant from the Dutch Ministry of Economic Affairs.

\section{Author Contributions}

Corné van Dooren designed and performed research and statistical analysis; Marcelo Tyszler and Gerard F. H. Kramer provided essential databases necessary for research and programmed the software; and Corné van Dooren and Harry Aiking wrote the paper. All authors have read and approved the final manuscript.

\section{Conflicts of Interest}

The authors declare no conflict of interest.

\section{References}

1. Brundtland, G.H. Our Common Future, Brundtland Report; UN: Oxfort, UK, 1987.

2. Food and Agriculture Organization (FAO). Biodiversity and sustainable diets united against hunger. In International Scientific Symposium; FAO Headquarters: Rome, Italy, 2010; p. 2.

3. Health Council. Guidelines for a Healthy Diet: The Ecological Perspective; Gezondheidsraad: The Hague, The Netherlands, 2011; p. 92.

4. Reddy, S.; Lang, T.; Dibb, S. Setting the Table, Advice to Government on Priority Elements of Sustainable Diets; Sustainable Development Commission: Londen, UK, 2009; p. 58.

5. Buchner, B.; Fischler, C.; Fitoussi, J.-P.; Monti, M.; Riccardi, G.; Ricordi, C.; Sassoon, J.; Veronesi, U. Double Pyramid: Healthy Food for People, Sustainable Food for the Planet; Barilla Center for Food \& Nutrition: Milan, Italy, 2010; p. 150.

6. Livsmedelsverket. The National Food Administration's Environmentally Effective Food Choices; Livsmedelsverket, National Food Administration Sweden: Stockholm, Sweden, 2009.

7. Gerlach, A.; Hohfeld, L.; Schamhorst, S.; Schudak, A. The Sustainable Shopping Basket; German Council for Sustainable Development: Berlin, Germany, 2009; p. 72.

8. Steering Group. Food for Tomorow, Proposal for Finland's National Food Strategy; Minister of Agriculture and Forestry: Helsinki, Finland, 2010; p. 24.

9. Federale Raad voor Duurzame Ontwikkeling (FRDO). Advice on Animal and Vegetable Proteins (in Dutch); Federale Raad voor Duurzame Ontwikkeling: Bruxelles, Belgium, 2011; p. 19.

10. Garnett, T. Three perspectives on sustainable food security: Efficiency, demand restraint, food system transformation. What role for LCA? J. Clean. Prod. 2014, 73, 10-18.

11. Garnett, T. Where are the best opportunities for reducing greenhouse gas emissions in the food system (including the food chain)? Food Policy 2011, 36 (Suppl. 1), S23-S32. 
12. DGAC. Scientific Report of the 2015 Dietary Guidelines Advisory Committee (Advisory Report). Available online: http:/health.gov/dietaryguidelines/2015-scientific-report/pdfs/scientific-reportof-the-2015-dietary-guidelines-advisory-committee.pdf (accessed on 16 September 2015).

13. Vringer, K.; Benders, R.; Wilting, H.; Brink, C.; Drissen, E.; Nijdam, D.; Hoogervorst, N. A hybrid multi-region method (HMR) for assessing the environmental impact of private consumption. Ecol. Econ. 2010, 69, 2510-2516.

14. Dutilh, C.; Kramer, K.J. Energy consumption in the food chain. Ambio 2000, 29, 98-101.

15. Tukker, A.; Huppes, G.; Guinée, J.; Heijungs, R.; de Koning, A.; van Oers, L.; Suh, S.; Geerken, T.; van Holderbeke, M.; Jansen, B.; et al. Environmental Impact of Products (EIPRO); IPTS/ESTO Project; European Commission: Brussels, Belgium, 2006; p. 139.

16. Herforth, A.; Frongillo, E.A.; Sassi, F.; Mclean, M.S.; Arabi, M.; Tirado, C.; Remans, R.; Mantilla, G.; Thomson, M.; Pingali, P. Toward an integrated approach to nutritional quality, environmental sustainability, and economic viability: Research and measurement gaps. Ann. N. Y. Acad. Sci. 2014, 1332, 1-21.

17. Health Council. Guidelines for Good Nutrition 2006 (in Dutch); Gezondheidsraad: The Hague, The Netherlands, 2006; p. 118.

18. World Health Organization (WHO). Diet, Nutrition and the Prevention of Chronic Diseases; WHO Technical Report Series; WHO: Geneva, Switserland, 2003.

19. Van Rossum, C.; Fransen, H.; Verkaik-Kloosterman, J.; Buurma-Rethans, E.; Ocke, M. Dutch National Food Consumption Survey 2007-2010: Diet of Children and Adults Aged 7 to 69 Years; RIVM: Bilthoven, The Netherlands, 2011; p. 144.

20. Van Dooren, C.; Marinussen, M.; Blonk, H.; Aiking, H.; Vellinga, P. Exploring dietary guidelines based on ecological and nutritional values: A comparison of six dietary patterns. Food Policy 2014, 44, 36-46.

21. Macdiarmid, J.I.; Kyle, J.; Horgan, G.; Loe, J.; Fyfe, C.; Johnstone, A.; McNeill, G. Livewell: $A$ Balance of Healthy and Sustainable Food Choices; WWF, Rowett Institute of Nutrition and Health: Aberdeen, UK, 2011; p. 64.

22. Maillot, M.; Darmon, N.; Drewnowski, A. Are the lowest-cost healthful food plans culturally and socially acceptable? Public Health Nutr. 2010, 13, 1178-1185.

23. Ferguson, E.L.; Darmon, N.; Briend, A.; Premachandra, I.M. Food-Based Dietary Guidelines Can Be Developed and Tested Using Linear Programming Analysis. J. Nutr. 2004, 134, 951-957.

24. Rambeloson, Z.J.; Darmon, N.; Ferguson, E.L. Linear programming can help identify practical solutions to improve the nutritional quality of food aid. Public Health Nutr. 2008, 11, 395-404.

25. Maillot, M.; Issa, C.; Vieux, F.; Lairon, D.; Darmon, N. The shortest way to reach nutritional goals is to adopt Mediterranean food choices: Evidence from computer-generated personalized diets. Am. J. Clin. Nutr. 2011, 94, 1127-1137.

26. Masset, G.; Monsivais, P.; Maillot, M.; Darmon, N.; Drewnowski, A. Diet Optimization Methods Can Help Translate Dietary Guidelines into a Cancer Prevention Food Plan. J. Nutr. 2009, 139, 1541-1548.

27. Metzgar, M.; Rideout, T.C.; Fontes-Villalba, M.; Kuipers, R.S. The feasibility of a Paleolithic diet for low-income consumers. Nutr. Res. 2011, 31, 444-451. 
28. Vieux, F.; Darmon, N.; Touazi, D.; Soler, L.G. Greenhouse gas emissions of self-selected individual diets in France: Changing the diet structure or consuming less? Ecol. Econ. 2012, 75, 91-101.

29. Wilson, N.; Nghiem, N.; Ni Mhurchu, C.; Eyles, H.; Baker, M.G.; Blakely, T. Foods and dietary patterns that are healthy, low-cost, and environmentally sustainable: A case study of optimization modeling for New Zealand. PLoS ONE 2013, 8, e59648.

30. Macdiarmid, J.I. Is a healthy diet an environmentally sustainable diet? Proc. Nutr. Soc. 2013, 72 , 13-20.

31. National Institute for Public Health and the Environment (RIVM). NEVO-table: Dutch Nutrient Database (in Dutch); RIVM: Bilthoven, The Netherlands, 2011.

32. Netherlands Nutrition Centre. Dutch Food Table 2008 (in Dutch); Voedingscentrum: The Hague, The Netherlands, 2008.

33. Marinussen, M.; Kramer, G.; Pluimers, J.; Blonk, H. The Environmental Impact of Our Food an Analysis Based on the Food Consumption Survey 2007-2010 (in Dutch); Blonk Consultants: Gouda, The Netherlands, 2012; p. 34.

34. Nationaal Instituut voor Budgetvoorlichting (NIBUD). The Cost of an Example Weekly Menu, Commissioned by the Nutrition Centre (in Dutch); National Institute for Family Finance Information (NIBUD): The Hague, The Netherlands, 2013; p. 14.

35. Health Council. Nutritional Guidelines for Energy, Protein, Fats and Digestible Carbohydrates (In Dutch); Health Council of the Netherlands: The Hague, The Netherlands, 2001; p. 174.

36. Health Council. Towards an Adequate Intake of Minerals and Vitamins (in Dutch); Gezondheidsraad: The Hague, The Netherlands, 2009; p. 100.

37. Goedkoop, M.J.; Heijungs, R.; Huijbregts, M.; de Schryver, A.; Struijs, J.; van Zelm, R. ReCiPe 2008, A Life Cycle Impact Assessment Method Which Comprises Harmonised Category Indicators at the Midpoint and the Endpoint Level; First Edition Report I: Characterisation; Pré Consultants: Amersfoort, The Netherlands, 2009.

38. Stocker, T.F.; Qin, D.; Plattner, G.-K.; Tignor, M.M.B.; Allen, S.K.; Boschung, J.; Nauels, A.; Xia, Y.; Bex, V.; Midgley, P.M. Climate Change 2013: The Physical Science Basis. Contribution of Working Group I to the Fifth Assessment Report of the Intergovernmental Panel on Climate Change; IPCC: Cambridge, UK; New York, NY, USA, 2013.

39. Bellows, A.C.; Alcaraz, V.G.; Hallman, W.K. Gender and food, a study of attitudes in the USA towards organic, local, U.S. grown, and GM-free foods. Appetite 2010, 55, 540-550.

40. Blonk, H.; Ponsioen, T.; Kool, A.; Marinussen, M. The Agri-Foorprint Method; Methodological LCA Framework, Assumptions and Applied Data; Blonk Milieu Advies: Gouda, The Netherlands, 2011; p. 111.

41. Joint Research Centre (JRC). ILCD Handbook: General Guide for Life Cycle Assessment-Detailed Guidance; European Commission, Joint Research Centre, Institute for Environment and Sustainability: Ispra, Italy, 2010; p. 417.

42. Sevenster, M.N.; Blonk, H.; van der Flier, S. Environmental Analysis of Food and Food Losses (in Dutch); CE Delft, Blonk Milieu Advies: Delft, The Netherlands, 2010; p. 78.

43. Dantzig, G.; Thapa, M. Linear Programming 1: Introduction; Springer-Verlag: New York, NY, USA, 1997. 
44. Smith, V.E. Linear Programming Models for the Determination of Palatable Human Diets. J. Farm. Econ. 1959, 41, 272-283.

45. Macdiarmid, J.I.; Kyle, J.; Horgan, G.W.; Loe, J.; Fyfe, C.; Johnstone, A.; McNeill, G. Sustainable diets for the future: Can we contribute to reducing greenhouse gas emissions by eating a healthy diet? Am. J. Clin. Nutr. 2012, 96, 632-639.

46. European Commission (EC). Climate Change Factsheet; European Commision: Brussels, Belgium, 2014; p. 6.

47. Vieux, F.; Soler, L.-G.; Touazi, D.; Darmon, N. High nutritional quality is not associated with low greenhouse gas emissions in self-selected diets of French adults. Am. J. Clin. Nutr. 2013, 94, 1127-1137.

48. Kuczynski, T.; Dämmgen, U.; Webb, J.; Myczko, A. Emissions from European Agriculture; Wageningen Academic Publishers: Wageningen, The Netherlands, 2005.

49. Weber, C.L.; Matthews, H.S. Food-Miles and the Relative Climate Impacts of Food Choices in the United States. Environ. Sci. Technol. 2008, 42, 3508-3513.

50. De Boer, J.; Helms, M.; Aiking, H. Protein consumption and sustainability: Diet diversity in EU-15. Ecol. Econ. 2006, 59, 267-274.

51. Thompson, S.; Gower, R.; Darmon, N.; Vieux, F.; Murphy-Bokern, D.; Maillot, M. A Balance of Healthy and Sustainable Food Choices for France, Spain, and Sweden. Available online: http://livewellforlife.eu/wp-content/uploads/2013/02/A-balance-of-healthy-and-sustainable-foodchoices.pdf (accessed on 17 September 2015).

52. Dantzig, G.B. The Diet Problem. Interfaces 1990, 20, 43-47.

53. Scarborough, P.; Allender, S.; Clarke, D.; Wickramasinghe, K.; Rayner, M. Modelling the health impact of environmentally sustainable dietary scenarios in the UK. Eur J. Clin. Nutr. 2012, 66, 710-715.

54. Ferguson, E.L.; Darmon, N.; Fahmida, U.; Fitriyanti, S.; Harper, T.B.; Premachandra, I.M. Design of Optimal Food-Based Complementary Feeding Recommendations and Identification of Key "Problem Nutrients" Using Goal Programming. J. Nutr. 2006, 136, 2399-2404.

55. Maillot, M.; Vieux, F.; Amiot, M.J.P.; Darmon, N. Individual diet modeling translates nutrient recommendations into realistic and individual-specific food choices. Am. J. Clin. Nutr. 2010, 91, 421-430.

56. Maillot, M.; Drewnowski, A. Energy Allowances for Solid Fats and Added Sugars in Nutritionally Adequate U.S. Diets Estimated at $17 \%-33 \%$ by a Linear Programming Model. J. Nutr. 2011, 141, 333-340.

57. Rao, M.; Afshin, A.; Singh, G.; Mozaffarian, D. Do healthier foods and diet patterns cost more than less healthy options? A systematic review and meta-analysis. BMJ Open 2013, 3, e004277.

58. Deloitte. Consumer Research 2013 (in Dutch); Deloitte: Amsterdam, The Netherlands, 2013; p. 76 .

(C) 2015 by the authors; licensee MDPI, Basel, Switzerland. This article is an open access article distributed under the terms and conditions of the Creative Commons Attribution license (http://creativecommons.org/licenses/by/4.0/). 